\title{
HUBUNGAN STRES BELAJAR DENGAN MOTIVASI BELAJAR PADA MAHASISWA YANG MENJALANI PENDIDIKAN DI SEKOLAH TINGGI ILMU KESEHATAN MURNI TEGUH
}

\author{
Muhammad Taufik Daniel Hasibuan \\ Program Studi Ilmu Keperawatan, STIKes Murni Teguh \\ E-mail : aniel.jibril@gmail.com
}

\begin{abstract}
Education is a process of learning from a knowledge, skills, attitudes and social behavior, which in undergoing the process must go through various stages to help achieve a goal. Students are expected to be able to go through all the learning processes in the education environment and this is related to learning stress which will ultimately affect learning motivation. This study aims to look at the relationship of learning stress with learning motivation in students undergoing education at STIKes Murni Teguh. This type of research uses cross sectional design and the sample used in this study amounted to 76 people, and simple random sampling is used as a sampling technique in the population. Research data collection using the SLSI questionnaire and learning motivation instruments, and analysis of the data used using the Spearman test. From the correlation test results obtained a significant relationship of $(0,000)$ and Correlation Coefficient of $(0.713)$, it can be concluded that stress learning has a relationship with student learning motivation. High learning motivation will make students study diligently and eventually will be realized in academic achievement. Efforts should be made to overcome the stress of learning and student motivation in undergoing the educational process to produce optimal learning.
\end{abstract}

Keywords : Stress Learning, Motivation To Learn, Students

\begin{abstract}
Abstrak
Pendidikan merupakan sebuah proses pembelajaran dari sebuah pengetahuan, keterampilan, sikap dan perilaku sosial, dimana dalam menjalani proses tersebut harus melewati berbagai tahapan untuk membantu tercapainya sebuah tujuan. Mahasiswa diharapkan dapat menjalani semua proses pembelajaran dilingkungan pendidikan dan ini berkaitan dengan stres belajar yang pada akhirnya akan mempengaruhi motivasi belajar. Penelitian ini bertujuan untuk melihat hubungan stres belajar dengan motivasi belajar pada mahasiswa yang menjalani pendidikan di STIKes Murni Teguh. Jenis penelitan ini menggunakan cross sectional design dan sampel yang dipakai dalam penelitian ini berjumlah 76 orang, serta simple random sampling dipakai sebagai teknik pengambilan sampel pada populasi. Pengumpulan data penelitian menggunakan kuesioner SLSI dan instrumen motivasi belajar, serta analisa data yang digunakan memakai uji Spearman. Dari hasil uji korelasi didapatkan hubungan yang signifikan sebesar (0.000) dan nilai Correlation Coefficient sebesar (0.713), maka dapat disimpulkan bahwa stres belajar memiliki hubungan dengan motivasi belajar mahasiswa. Motivasi belajar yang tinggi akan membuat mahasiswa belajar dengan tekun dan pada akhirnya akan terwujud dalam prestasi akademik. Perlu dilakukan upaya untuk mengatasi stres belajar dan motivasi belajar mahasiswa dalam menjalani proses pendidikan untuk menghasilkan pembelajaran yang optimal.
\end{abstract}

Kata Kunci : Stres Belajar, Motivasi Belajar, Mahasiswa 


\section{PENDAHULUAN}

Pendidikan merupakan sebuah proses pembelajaran dari sebuah pengetahuan, keterampilan, sikap dan perilaku sosial, dimana dalam menjalani proses tersebut harus melewati tahapan yang telah dibuat untuk membantu tercapainya sebuah tujuan. Pembelajaran merupakan proses yang sangat penting dari sebuah pendidikan, dan diharapkan mahasiswa dapat menjalani proses pembelajaran dan hal ini berkaitan dengan stres dan motivasi (Fenti, 2010)

Tuntutan akademik yang harus dijalani akan menjadi faktor pemicu dari permasalahan yang dihadapi mahasiswa. Kehidupan akademik bukan hanya datang kekampus, menghadiri kelas, ikut dalam ujian dan akhirnya lulus, akan tetapi banyak proses yang harus dilalui dan ini berhubungan dengan stres dan motivasi belajar, Menurut Mc Nerney dalam Yosep (2007) stres merupakan reaksi dari fisik, mental, dan kimiawi dari tubuh terhadap situasi yang mengejutkan, menakutkan, membingungkan, merisaukan dan membahayakan seseorang.

Ketidaksesuaian antara tuntutan dan kemampuan akan menghasilkan suatu permasalah seperti stress, dan masalah yang sering terjadi dilingkungan pendidikan adalah stress belajar. Menurut Looker dan Gregson (2005) stres belajar merupakan suatu keadan individu yang mengalami tekanan hasil persepsi dan penilaian tentang stressor akademik, yang berhubungan dengan belajar dilingkungan sekolahnya dan mahasiswa cederung akan mengalami stres belajar. Menurut Hawari (2011) bentuk dari stres dilingkungan pendidikan adalah merasa takut menghadapi ujian, merasa tidak percaya diri dalam tindakannya, merasa tidak mampu mengerjakan tugas-tugas yang diberikan, kecewa, dan merasa gurunya tidak adil. Wlodkowski (2004) menyatakan jika seorang mahasiswa ingin mencapai kesuksesan dibandingkan dengan pencapaiannya saat ini, kuncinya adalah jangan pernah berhenti belajar.
Stres yang terjadi pada setiap individu akan memiliki perbedaan, dimana hal ini dipengaruhi oleh beberapa faktor seperti fungsi fisiologis, kepribadian, karakteristik perilaku, dan karakteristik stressor yang dialami dimana mencakup durasi, intensitas, jumlah, cakupan, dan sifat stressor itu sendiri. Menurut Gadzella (2001) terdapat lima kategori stressor yang akan dialami mahasiswa yaitu tekanan, frustasi, konflik, perubahan-perubahan dan keinginan diri.

Adanya motivasi belajar yang tinggi membuat mahasiswa belajar dengan tekun, yang pada akhirnya akan terwujud dalam prestasi akademik. Perlu ditanamkan pada diri mahasiswa bahwa dengan belajar akan mendapatkan pengetahuan yang baik, dan mahasiswa akan mempunyai bekal menjalani kehidupannya dikemudian hari. Hal yang mempengaruhi motivasi belajar mahasiswa dapat berasal dari dirinya sendiri, lingkungan sekolah maupun dari lingkungan keluarga. Mahasiswa yang tidak memiliki motivasi belajar akan dapat menyebabkan prestasi belajarnya menurun (Hakim, 2001).

\section{METODE PENELITIAN}

Jenis penelitian ini adalah kuantitatif dengan cross sectional design. Teknik pengambilan sampel menggunakan simple random sampling dengan jumlah sampel 76 orang yang berstatus sebagai mahasiswa. Penelitian ini telah dilakukan di STIKes Murni Teguh pada bulan Februari-Mei 2019.

Pengumpulan data penelitian menggunakan kuisioner, dimana pengukuran stres belajar menggunakan instrumen student life stress inventory (SLSI), dan pengukuran motivasi belajar menggunakan instrumen yang dikembangkan oleh peneliti. Instrumen ini telah dilakukan uji validitas dengan nilai CVI (0.99 dan 0.98). Hasil data penelitian dianalisa menggunakan uji Spearman.

Tahapan dalam proses penelitian, yaitu 1) Tahap pertama : peneliti meminta izin kepada calon responden dan memberikan format data demografi, 2) Tahap kedua : peneliti mengajukan kuisioner dan mengukur tingkat stres dan motivasi belajar mahasiswa, 
3) Tahap ketiga : peneliti melakukan analisis data univariat dan bivariat dengan menghubungkan antara variabel independent dan variabel dependent dengan memakai sistem komputerisasi.

\section{HASIL PENELITIAN}

\section{Karakteristik Responden ( $N=76)$}

Data demografi menunjukkan bahwa mayoritas responden berada pada usia 16-20 tahun $(76.3 \%)$, dan jenis kelamin perempuan sebanyak $71(93.4 \%)$.

\section{Stres Belajar Pada Mahasiswa Yang Menjalani Pendidikan}

Dari hasil penelitian didapatkan nilai distribusi frekuensi stres belajar adalah kategori ringan $46(60.5 \%)$, sedang 27 (35.5\%), dan berat 3 (3.9\%).

Tabel 1. Distribusi Frekuensi, Persentase Pada Stres Belajar Mahasiswa Yang Menjalani Pendidikan (N=76)

\begin{tabular}{ccc}
\hline \multirow{2}{*}{ Stres Belajar } & Frekuensi & Persentase \\
\cline { 2 - 3 } & $\mathbf{n}$ & $\mathbf{\%}$ \\
\hline Stres Belajar Ringan & 46 & 60.5 \\
\hline Stres Belajar Sedang & 27 & 35.5 \\
\hline Stres Belajar Berat & 3 & 3.9 \\
\hline Total & 76 & 100 \\
\hline
\end{tabular}

Motivasi Belajar Pada Mahasiswa Yang Menjalani Pendidikan

Dari hasil penelitian didapatkan nilai distribusi frekuensi motivasi belajar adalah kategori tinggi 33 (43.4\%), sedang 42 $(55.3 \%)$, dan rendah $1(1.3 \%)$

Tabel 2. Distribusi Frekuensi, Persentase Pada Motivasi Belajar Mahasiswa Yang Menjalani Pendidikan (N=76)

\begin{tabular}{ccc}
\hline \multirow{2}{*}{ Motivasi Belajar } & Frekuensi & Persentase \\
\cline { 2 - 3 } & $\mathbf{n}$ & $\mathbf{\%}$ \\
\hline Motivasi Belajar Tinggi & 33 & 43.4 \\
\hline Motivasi Belajar Sedang & 42 & 55.3 \\
\hline Motivasi Belajar Rendah & 1 & 1.3 \\
\hline Total & 76 & 100 \\
\hline
\end{tabular}

Hubungan Stres Belajar Dengan Motivasi Belajar Pada Mahasiswa Yang Menjalani Pendidikan

Dari hasil penelitian didapatkan hubungan yang signifikan antara stres belajar dengan motivasi belajar pada mahasiswa yang menjalani pendidikan, dengan nilai Sig. (2-tailed) sebesar 0.000, dan nilai Correlation Coefficient sebesar 0.713 .

Tabel 3. Uji Spearman Hubungan Stres Belajar Dengan Motivasi Belajar Mahasiswa Yang Menjalani Pendidikan (N=76)

\begin{tabular}{lcc}
\hline Spearman & $\begin{array}{c}\text { Correlation } \\
\text { Coefficient }\end{array}$ & $\begin{array}{c}\text { Sig. } \\
\text { (2-tailed) }\end{array}$ \\
\cline { 1 - 1 } Stres Belajar & 0.713 & 0.000 \\
\cline { 1 - 1 } Motivasi belajar & & \\
\hline
\end{tabular}

\section{PEMBAHASAN}

Dari hasil penelitian yang dilakukan peneliti didapatkan hubungan yang signifikan antara stres belajar dengan motivasi belajar, dengan nilai sig. 0.000. Hal ini membuktikan bahwa stres belajar memiliki hubungan yang kuat terhadap motivasi belajar mahasiswa. Menurut asumsi peneliti bahwa dengan adanya stres belajar akan memicu terjadinya penurunan motivasi belajar pada mahasiswa dan pada akhirnya akan mempengaruhi prestasi akademik mahasiswa.

Stres belajar merupakan keadaan individu yang mengalami tekanan hasil persepsi dan penilaian tentang stresor akademiknya, yang dapat diartikan sebagai bentuk dari kejenuhan terhadap rutinitas dari kegiatan belajar yang dilakukan mahasiswa secara terus menerus. Sedangkan motivasi belajar adalah dorongan internal dan eksternal pada siswa yang sedang belajar, dimana bertujuan untuk melakukan perubahan yang lebih baik (Uno, 2011).

Menurut Winkel (2004) motivasi dapat menentukan sebuah capaian dari tujuan seseorang, dimana semakin besar motivasi akan semakin besar kesuksesan yang diraih. Menurut Sardiman (2014) motivasi tumbuh didalam diri individu. Motivasi berfungsi sebagai penggerak didalam kegiatan belajar, menjamin kelangsungan dari kegiatan 
belajar, dan memberikan arah pada kegiatan belajar, sehingga tujuan yang dikehendaki oleh seseorang dapat tercapai. Menurut Wlodkowski (2004) motivasi belajar sangat penting didalam pengembangan diri, karena pengembangan diri adalah belajar.

\section{KESIMPULAN}

Kesimpulan hasil penelitian ini adalah :

1. Terdapat hubungan yang signifikan antara stres belajar dengan motivasi belajar pada mahasiswa yang menjalani pendidikan

2. Mayoritas usia responden berada pada usia 16-20 tahun (76.3\%), dan jenis kelamin perempuan sebanyak 71 (93.4\%).

\section{SARAN}

1. Bagi Mahasiswa

Hasil penelitian ini diharapkan menjadi informasi yang baik bagi mahasiswa untuk dapat mengantisipasi terjadinya stres belajar dan terus meningkatkan motivasi dalam belajar untuk meraih prestasi akademik yang lebih baik.

2. Bagi pendidikan

Hasil penelitian ini diharapkan menjadi informasi yang baik bagi instansi pendidikan untuk dapat membuat suatu upaya dalam mencegah terjadinya stres belajar dan meningkatkan motivasi belajar pada mahasiswa yang menjalani masa pendidikan.

3. Bagi penelitian selanjutnya

Penelitian tentang stres belajar dan motivasi belajar pada mahasiswa perlu dilanjutkan. Disarankan pada penelitian selanjutnya untuk membahas tentang cara mengatasi stres belajar dan meningkatkan motivasi belajar mahasiswa, disamping itu juga perlu menambahkan variabel lain dalam memperkaya bahasan penelitian.
Gadzella, B.M. et all. (2001). Confirmatory factor analysis and internal consistency of the student life-stress inventory. Journal of Instructional Psychology/Student Life-Stress Inventory.

Hakim, Thursan. (2001). Belajar secara efektif. Jakarta : Puspa Swara

Hawari, D. (2011). Manajemen stres cemas dan depresi. Jakarta : Balai penerbit FKUI.

Looker, Terry., \& Gregson, Olga. (2005). Managing stres "mengatasi stres secara mandiri". Yogyakarta : Baca.

Sardiman, A.M. (2014). Interaksi dan motivasi belajar. Jakarta : PT Raja Grafindo Persada.

Uno, Hamzah. (2011). Teori motivasi dan pengukurannya. Jakarta : Bumi Aksara.

Winkel. (2004). Pengertian motivasi. Jakarta : Bumi Aksara.

Wlodkowski, R, J. (2004). Hasrat untuk belajar. Yogyakata : Pustaka Pelajar

Yosep, Iyus. 2007). Keperawatan jiwa. Bandung : Refika Aditama

\section{REFERENSI}

Fenti, H. (2010). Bimbingan konseling. Jakarta : Rajagrafindo. 